\title{
China and India: On the Edge of Water Disputes and Co-operations
}

\author{
Naila Afzal*, Dr. Zahid Yaseen**, Dr. Muhammad Muzaffar***
}

\begin{abstract}
This study explores the scarcity of water within two populous states of the world, World has challenge of water war owing the water conflict between the two thirsty nations of the world that might transfer into global war. Qualitative as well as quantitative research methodology was used. Ramification of the study is founded under the current diplomatic and bilateral scenario of the two states, upper riparian states of the region including China and India wanted to divert river water flow to avoid water scarcity in future that might damage agriculture and industry of lower riparian states. It is also recommended that United Nation and other International Organizations should play their part and introduce agreed law and policy of water distribution for the protection of global water conflict.
\end{abstract}

Key Words: Ghaghara River, Kosi River, and Brahmaputra River.

This Article can be cited as:

Afzal N., Yaseen Z., Muzaffar M., (2020). China and India: On the Edge of Water Disputes and Co-operations, Journal of Arts and Social Sciences. VII (2), 231-244.

\footnotetext{
* Naila Afzal, Ph.D Scholar, Department Political Science, GC Women University Sialkot, Punjab, Pakistan.

** Correspondence concerning this article should be addressed to Dr. Zahid Yaseen, Assistant Professor, Department Political Science, GC Women University Sialkot, Punjab, Pakistan, zahid.yaseen@gcwus.edu.pk .

*** Dr. Muhammad Muzaffar, Assistant Professor, Department Political Science, GC Women University Sialkot, Punjab, Pakistan.
} 


\section{Introduction}

The present study has done to reveal the budding water conflict between the two thirsty nations of China and India. The crucial point of conflict is emerged from Himaliyan region where largest river of the world "Brahmaputra" flow from Southern Tibet an autonomous region of China, pass through India and Bangladesh, before fall into the Bay of Bengal merged with Ganges river. (Chellanely, 2013) Water shortage is the burning issue of all the growing populous and economic riparian states. After the construction of major hydropower dam "Zangmu" in China late 2014, it has been alarming that China and India might have water wars on the sharing border during the existed decade. (Samaranayake, Limaye, \& Wuthnow, 2018)Now the two populous states of Asia have been facing serious threat to their relations owing climate change, and rising demand of water. Water wars rhetoric exist early and this rhetoric help a lot to examine and analysis in depth the sensitive water issue between China and India. This study has organized to ascribed the connected rivers between China and India and explore the most serious water dispute of Brahmaputra and agreement to resolve the issue. (Bajpai, B. , Huang, J. , \& Mahabubani, K. 2016)

\section{Historical Background}

China and India the two populous states of the world existed in Asia and located in Southeast Asia. Both states shared coastline on the Pacific Ocean. After Russia and Canada, China is the third largest country by holding the area of 9.6 million square $\mathrm{km}$ and $18000 \mathrm{~km}$ coastline. Its shape is like a rooster on the map. (Wirsing, Jasparro, \&Stoll, 2013) Its northern border ended with the territory of Mohe in province of Heilongjiang, West border with the Pamirs, southern border connected with the territory of Zengmu Ansha (James Shoal), and eastern border expanded to the Heilongjiang conjunction river Amur and Wusuli river (Ussuri), straddling about $62 \%$ of Longitude and $50 \%$ of latitude.

China shared border with 14 countries of Russia, Mongolia, Kazakstan, Kyrgyzstan, Tajkistan, Afghanistan, Pakistan, Nepal, Bhutan, India, Burma, Laos, Vietnam, and Korea. (Chellanely, 2013) Vietnam, Malaysia, Indonesia, Brunei, Philipines, Japan, Korea, and North Korea are eight countries of Marine side. China shared $3488 \mathrm{~km}$ border with India being her immediate neighbor along with states of Uttarkhand and Arunachal Pradesh, Sikkim, Himachal Pradesh, and Jammu and Kashmir. Both states also facing boundary issues. India also shared border with China, Nepal, Bhutan, Bangladesh, Myammar, and Pakistan. The study discuss the territory connected China and India. (Xie, 2018)

\section{Rivers Connected India and China}

The two populous states of the world China and India not only shared border but also connected by rivers. Four major rivers across the border connected India and China.

Table 1. Rivers Connected China and India

\begin{tabular}{|c|c|c|c|c|c|c|c|c|}
\hline S.N & Rivers & China(Tibet) & India & Pakistan & Afghanistan & Nepal & Bhutan & Bangladesh \\
\hline 1 & $\begin{array}{l}\text { Indus/Shiquan } \\
\text { River }\end{array}$ & $8 \%$ & $39 \%$ & $47 \%$ & $6 \%$ & $\begin{array}{l}------- \\
-- \\
\end{array}$ & $\begin{array}{l}------------ \\
-\end{array}$ & \\
\hline 2 & Ghaghara rive & Generated & $45 \%$ & --------- & ----------- & $55 \%$ & $\begin{array}{l}---\cdot------ \\
--\end{array}$ & ------------ \\
\hline 2 & Kosi River & Generated & $20 \%$ & ---------- & & $\begin{array}{l}80 \% \\
\text { (Tibet } \\
\& \\
\text { Nepal) }\end{array}$ & $\begin{array}{l}------------ \\
-\end{array}$ & \\
\hline
\end{tabular}




\begin{tabular}{|l|l|l|l|l|l|l|l|l|}
\hline 3 & $\begin{array}{l}\text { Brahmaputra } \\
\text { River }\end{array}$ & $51.1 \%$ & 34.0 & -------- & --------- & ------ & $6.7 \%$ & 8.2 \\
\hline
\end{tabular}

Sources: (Food and Agricultural Organization, February 10, 2011), (Uprety, \& Salman, 2002), (Mohan, 2018), (Kumar, 2015).

1. The Indus/Shiquan River immediately connected China, India, and Pakistan.

2. The Ghaghara river connected China, India, Nepal.

3. The Kosi connected China, Nepal, and India.

4. The Brahmaputra River connected India, China, Bangladesh, and Bhutan.

China and India clearly not shared any river, crossborder rivers also share water with other neighboring states. China shared all rivers being upper riparian state, India being middle riparian state in the river of Satlej, Indus, and Brahmaputra, India shared water being lower riparian state in other two rivers of Kosi and Ganga. Although China shared all rivers being upper riparian state but it occupied only Brahmaputra's significant parts. Brahmaputra has become the most serious conflict among all shared rivers. (Xie, 2018).

\section{The Indus/Shiquan River immediately connected China, India, and Pakistan}

The inter connected Indus river Basin covered the area of 1.12 million kilometer by sharing water between China, India, Pakistan, and Afghanistan with the percentage of 8\%, 39\%, 47\%, $6 \%$ subsequently. From North Indus river Basin originated in Himaliyan range to south in dry alluvial plains in Pakistan's Province of Sindh and eventually fall hooked on the Arabian Sea. The Indus river Basin comprising on the Province Punjab, Khyber Pakhtunkhwa, major territory of the Province of Sindh and eastern territory of Baluchistan Province by covering the area about 520,000 km2/65 \% territory of Pakistan. In India Indus river Basin comprises on the state of Chandigarh, Haryana, Rajasthan, Punjab, Himachal Pradesh and Jamu and Kashmir by covering the territory of $440,000 \mathrm{~km} 2$, that is about $14 \%$ total area of India. The river covered only $14 \%$ catchment area in China that is about only $1 \%$ territory of country. In Afghanistan it covered $11 \%$ area of the country. Estimate 300 million population lived around the Indus river Basin. The area does not cover the standardized climate. (Uprety, \& Salman, 2002).

"It varies from subtropical arid and semiarid to temperate subhumid on the plains of Sindh and Punjab provinces to alpine in the mountainous highlands of the north. Annual precipitation ranges between 100 and $500 \mathrm{~mm}$ in the lowlands to a maximum of $2000 \mathrm{~mm}$ on mountain slopes. Snowfall at higher altitudes (above $2500 \mathrm{~m}$ ) accounts for most of the river runoff"' (Ojeh, 2006).

Table 2. Coverage Area of Rivers

\begin{tabular}{|l|l|l|l|l|}
\hline River & China & India & Pakistan & Afghanistan \\
\hline Indus river Basin & $8 \%$ & $39 \%$ & $47 \%$ & $6 \%$ \\
\hline Area Covers & $14 \%$ catchment area/ & $440,000 \mathrm{~km} 2$ & $520,000 \mathrm{~km} 2$ & $11 \%$ area of country \\
& $1 \%$ country & $14 \%$ of country & $65 \%$ of country & \\
\hline
\end{tabular}

Source: (Uprety, \& Salman, 2002)

\section{The Ghaghara river connected China, India, Nepal}

In the southwestern Tibet Mount Kailash bestow with the largest rivers of Asia including Karnali, Indus, Sutlej, and Brahmaputra. Mount Kailash revered being a sacred place by the Jains, Bons, Buddhist, and Hindus. One of the four rivers Karnali is largest river of Nepal, flowed from North to South through deep gorges to the Indian state of Uttar Pradesh where it called Ghaghara River, tributary of Ganga River. The Ghaghara River originated in Tibetan Plateau near Lake Mansarover in the Mapchachungo glaciers with the height of 4800 meter. Catchment of Ghaghara river is $127,950 \mathrm{~km}^{2}$. It lies about 55 percent in 
Nepal. After travelling through Himalaya in Nepal, it joined Sharda River at Brahma Ghat in India. Where 45 percent of the river lies in India. (Uprety, \& Salman, 2002).

"Average annual water yielded due to the rain fall in Ghaghara basin for river Ghaghara is reported to be 94,400 million $m$. The ground water level data of the Ghaghara basin districts reveals that range of ground water level is from 0.91 to $8.58 \mathrm{~m}$ bgl in premonsoon and 0.4 to $7.46 \mathrm{~m}$ bgl in post monsoon season. The Ghaghara plains are underlain by thick loose alluvial sediments deposited by the River Ghaghara and tributaries." (Ojeh, 2006).

The surface slopes towards southeastwards except near river banks. The region exhibited river vally terrace surface, upland terrace surface, in present days river channelled with the point bar deposits, natural level, and narrow flood plains by geomorphologically. Saryu canal system, Sarada Sahayak, and Sarada provided irrigation in the Ghaghara basin. (Singh, 2017) Although entire Ghaghara basin has been effected by the floods but Bahraich, Gonda, Ballia, Azamgarh, Kushinagar, Maharajganj, au, Siddhartha Nagar, Sant Kabir Nagar, Deoria, and Gorakhpur districts worstly proned of floods. The reason of worst floods in Ghaghara region is its marginal length that is about 586.77 kilometre. Today there is no any environmental issue in Ghaghara region like acid rains, global warming, and ozone depletion, but the increasing demand of resources marginalized the environmental priorities of the basin like agricultural productivities, attention on industries, concentrated and increasing generation of pollution and wastes, migration to urban areas, rapid urbanization, land and water, load on air, and changing landuse patterns. (Adeel, \& Wirsing, 2017).

\section{The Kosi connected China, Nepal, and India}

The river Kosi originated from Tibet and by passing through Nepal joins Ganges River in India in the district of Bihar. $88000 \mathrm{~km}^{2}$ total drainage area is covered by Kosi river, $80 \%$ Covered by Tibet and Nepal and 20\% India. Kosi River originated at an altitude about over $7000 \mathrm{~m}$ above MSL in Himalayas, 6 of 14 eight thousanders are in basin of Shishapangma, Cho Oyo, Makalu, Lhotse, Kangchenjunga, and Mount Everest. (Lohani, 2013) Kosi is the largest river of Nepal where it called Septa Kosi after Tibetan Confluence. The length of Kosi River is $270 \mathrm{~km} \mathrm{N-S,} \mathrm{S-W} \mathrm{and} \mathrm{width} \mathrm{is} 145 \mathrm{~km} \mathrm{~N}-\mathrm{E}, \mathrm{S}-\mathrm{W}$, with the catchment area of $25,600 \mathrm{sq} . \mathrm{km}$. Its total drainage area is $92,538 \mathrm{sq} . \mathrm{km}$, Tibet covered 30,800 sq.km, Nepal 41,333sq km, and India 20,405 sq km. Kosi River flow from a narrow gorge for $10 \mathrm{~km}$ before entering the plains at Chatra, after another $25 \mathrm{~km}$ it enters in India near Hanumangarh and $20 \mathrm{~km}$ further downstream it joins the Ganges near Khursela in the state of Bihar. Kosi River is also called the "sorrow of Bihar" owing of seasonal disaster. (Bahadur, 2004).

\section{The Brahmaputra River connected India, China, Bangladesh, and Bhutan}

The river Brahmaputra originated in Tibet. It is about 2880 kilometer long. It is known as yarlung Tsangpo in Tibet. Through southern Tibet it flowed to eastward with the distance of $1625 \mathrm{~km}$, and in the most eastern point it turns to Great Bend or Shoumatan Point before entering the most eastern state of India Arunachal Pradesh. Where it known Siang river. In the state of Assam it announced itself as Brahmaputra after gather water of several rivers. Then entered in Bangladesh by the river of Snakes Lazily in Assam. Here it is famous with the name of Jamuna. By joining thte river of Ganges (Padma in Bangladesh) and the river Meghna, both these rivers from the biggest delta of the world prior empting water into Bay of Bengal. Water conflict between the giants of Asia is a significant task for sufficient management of basin. (Samaranayake; Limaye; \& Wuthnow, 2018).

Table 3. Brahmaputra River: Water Distributing Areas

\begin{tabular}{|l|l|l|ll|l|}
\hline States & River \% & Covered State Area & $\begin{array}{l}\text { Hydro } \\
\text { Potential }\end{array}$ & Power & $\begin{array}{l}\text { Total } \\
\text { Potential of Basin \% }\end{array}$ \\
\hline China & 51.1 & 3.1 & 110 & 53.4 \\
\hline
\end{tabular}




\begin{tabular}{|l|l|l|l|l|}
\hline Bhutan & 6.7 & 100 & 30 & 14.6 \\
\hline India & 34.0 & 5.10 & 66 & 32 \\
\hline Bangladesh & 8.2 & 32.64 & 0 & 0 \\
\hline Total & 100 & & 206 & 100 \\
\hline
\end{tabular}

Sources: (Sarma, 2005), (NHPC, 2008), (Tianchau, 2001), (World Bank, 2008), (Rangachari\&Verghese, 2001), (CWC, 2008), (DOT, 2007), (NBP, 2008)

There are three major reasons.

\section{China Occupied Point}

The first major reason of conflict is that although shared water of four rivers being upper riparian state but it occupied only Brahmaputra River significant part. China covered 50 percent area of river Brahmaputra, consequently activities of China over Brahmaputra river left crucial impact among the four rivers.

\section{Significance of Brahmaputra}

Significance of Brahmaputra river is equal to the both states of China and India. It covered 30 percent freshwater resources of India and covered about 40 percent of India's hydropower potential. While on the side of China Brahmaputra river role is limited at national level, as it is generated from Tibet and move towards eastern side instead of western side, therefore it has immense importance for Tibet and significant for energy and agricultural sector of Tibet. (Rahaman, Varis, 2009).

\section{Linked to the Disputed border}

Third one reason of the water conflict between the two states is it linked the two states on disputed border. China and India has also challenges on the claim of Eastern Himaliyas that is the triple junction between the three states of China, Bhutan, and India, from the west of Brahmaputra River to the east along with the Himalayan range. The conflicted territory between the two states is known as Arunachal Pradesh in India and in China it is South Tibet. Onemillionpopulation and about $90,000 \mathrm{~km}^{2}$ area covered by disputed area.

\section{Rise of Water Conflict between India and China}

Since the last decade a number of research papers including national and international, South China morning Post, the Guardian, the New York Times, national newspaper of India including DNA, the Indian Express, India Today, and the Times of India kept warning of expected water wars between India and China. The most leading magazines like Geopolitical Monitor, World Review, the Project Syndicate, World Affairs, and the Economist have also been published on the aspects of Sino-Indian water disputes. A number of academic papers and reports published on the Chinese commitment of constructing a larger dam on Brahmaputra river than can be raise border disputes. In many publication of Sino-India water Wars the most influential book is "Water, Peace and War: Confronting the Global Water Crisis" and other "Water: Asia's New battleground" meet to award written by Dr. Brahma Chellaney. He argued that in past battles were fought for land, in present for energy but in future wars would be wagged over water. Former chief of Army of India General S. Padmanabhan wrote a book in October 2014, entitled with "Next China-India War: World's First Water War-2029". In his book he bickered that China expected tohave sever water shortage in future that is why it begun to divert Brahmaputra river that would become the reason of full scale war between India and China. The current Prime Minister of India Narender Modi expressed his concerns over water projects of China on Brahmaputra River during his campaign in Haryana. He claimed that China is being striving to stop the flow of Brahmaputra River. (Bajpai, Huang, \& Mahabubani, 2016) On the first visit of Xi Jinping to India in September 2014, Chief minister of Assam (state of Northeast India) Mr. Tarun 
Gogoi sent a letter to PM Narinder Modi and requested to raise the question on Chinese strategy of constructing dams on Brahmaputra River that would impact adversely on downstream flow of river. By adding he claimed that people expecting water wars between India and China on Brahmaputra perceived three subsequent reasons.

- First:China is expected serious water shortage in the coming decades, and to counter the challenge China will outset the strategy to divert Brahmaputra water flow towards its dry areas of north. Many of people believed that China has already been planned to divert Brahmaputra water flow towards its dry areas of north.

- Second:It is also believed that China's initiative to divert water flow can bring catastrophe to the downstream countries.

- Third:They also pointed out unwillingness of China to come over any peace agreement over trans boundary rivers among the downstream countries. It is also prevailed that China wants absolute sovereignty over water principles.

They also bickered that the principle of absolute sovereignty would pose harm to downstream territory and create frustration among the downstream countries. India couldn't find the satisfactory response from China. Indeed China has been faced water stress. Water scarcity in China driven by the rapidly raising urbanization and industrialization along with pollution. (Chellanely, 2013) To deal with water challenges china has record mega infrastructure projects including South North Water Diversion (SNWD), and Three Gorge Dams. China also deniesaccepting the UN 1997 convention on the Law of the Non Navigational Use of International Water Courses (UNWC). However China is not following any water diversion project in Tibet. Indian media, security analysts and politician over react on the water wars between India and China. Repeatedly China assured India to avoid diverting flow of Brahmaputra River and they would have serious concerns to downstream countries when they will plan to build a dam. Chinese scholars argued that Indians have over exaggerated the Chinese threat. Some of Chinese scholars argued that India has raised deliberately the water conflict because India by self has planned to construct dam along the Brahmaputra River section. (Purity, \& Salman, 2002).

\section{Water Diverting Idea}

China and India both suffering from exacerbate water shortage; by forcefully they could plan to construct dam that would cause to lead tension. The International Conference of Global Infrastructure Fund in Anchorage that was held in Alaska in 1986, first talk about the idea of diverting flow of Brahmaputra River. The book Tibet's Water will save China published in 2005, this book limelight the water conflict between India and China. ( $\mathrm{Li}, 2005$ ) prior to this book in 2003 people daily accounted to launch the feasible study over diverting Brahmaputra River (Hughes, 2013). In the way of uneven division of water among the Chinese territory, China has worst challenges of water. (Govt of China) Indeed China has been faced water stress. Water scarcity in China driven by the rapidly raising urbanization and industrialization along with population. The urban areas need of water has been increased from 65 to 100 percent for next twenty years. Water requirements and hydro projects of China have bring the country on the edge of water disputes with neighboring states. While water conflicts already existed between cities, energy, and agriculture. (Addams et al, 2009)

Existing data apparent that china covers the $22 \%$ population of the world while securing $7 \%$ fresh water of the world to meet up the needs. The uneven water division among the country is another issue. The environmental impact and decreasing water flow together influenced the local livelihood and irrigation practices that enhance the intensity of the water crisis. In the result of climate change the Himaliyan glaciers continuously melting and decreasing flow of Brahmaputra river uplift the immediate impact on water borne diseases, water availability, and human life. (Harris, 2001) 
The spread of irrigated farming and water intensive industries have led to serve struggle for more water. Both are in the era perennial water scarcity. A large population, ineffective water sharing, water shortages, rising demand of middle class, and melting glaciers badly affected the rivers originated in the Tibetan Plateau that leads to tension. In order to overcome hydrological unevenness, projects like the "South to North water diversion" was first proposed by chairman Mao in 1952 to reduce water shortages in the cities like Beijing \& Tianjin. Later on faced with acute water shortage, China proposed for water diversion projects namely-the South North Water Diversion Project and the Great Western Route Diversion Project. There are two project behind the planning of Yarlung projects.

1. To generate hydro Power

2. To reroute the Brahmaputra's water to the dry yellow river in the North Western provinces of Xinjiang and Gansu.

Tibet is the second largest province of China after Xinjiang. The existing water resources in Tibet are estimated to be 40,000 times higher than in China. The largest Indian river flow from Tibet. Tibet is the world's largest source of fresh water than polar ice caps. Tibet Plateau is the major source of water resources of upstream canals, dams, barrages. (Chellanely, 2009).

Primary desire of China is to reduce its reliance on fossil fuels. To meet energy demand in future China endeavoring to double its electricity generating capacity from $960 \mathrm{GW}$ in 2010 to 1900 gigawatts in 2020. China strategy for food sufficiency is projection of huge hydroelectricity for energy and water diversion scheme. (Sinha, 2012). The high dependence on coal has also given the dubious distinction of being world's top emitter of green house gases. This factor demanded to think again the Scientific Development Concept for a balance and sustainable development. China's new energy policy then emphasized upon hydro and nuclear power. The extractions of Tibet's untapped natural resources are supposed to fuel the economic integration and stability. Increasing hydropower resources facilitates China to reduce the income gap between its western regions and eastern provinces. Selling electricity to its neighbours will promote robust relations across the border, that would be lucrative for China's western regions development. Appart from it energy is crucial important in the Tibet autonomous region for tapping significal reserves of iron, zinc, copper, lithium, chromite, borax, and uranium etc.(Navrud \& Godwin, 2020).

\section{Construction of Hydro Project on Brahmaputra}

China has utmost concern to the lower riparian states by constructing hydro projects on Brahmaputra. China has planned more than four hundred dams for new projects proposed over twenty years with over 160,000 Mega Watt across the border including Bhutan, Nepal, India, and Pakistan. Himalaya region expected to get crucial concentration of dams over the globe by putting into action these plans with far reaching implications for economy, landscape and ecology of the region. (Walker, 2014) India has also been planned dams on Brahmaputra about 150 mega and micro hydel projects in the Arunachal Pradesh in the Northeast. That can be change the flow of water in the Brahmaputra and causing disastrous impact on the rich bio diversity of the region (Ramachandran, 2015).

The water diversion plan on Brahmaputra might to have disastrous impact on livelihoods down streams and lives, ecology, agriculture and water flow. China has greatest concern with lower riparian states for building dams on Brahmaputra. (Iyer, 2015). He points out that there is a break in the river between the point of diversion to the turbines and points of return of water to the river and the break can be very long upward of $10 \mathrm{~km}$ in many cases even $100 \mathrm{~km}$ in some cases and there would be a series of such breaks in the river of a cascade of projects. 
In such projects the turbines operate intermittently in accordance with the market demand for electricity which means that the waters have been held back in pondage and released when the turbines need to operate in the result of huge diurnal variations from 0 percent to 400 percent within a day in downstream flow. It is observed that in the four hours eight meter water wall rushed in the down river and 20 hours remained dry. No aquatic life or riparian population can cope with that order of diurnal variation. (Gill, 2017) Downstream areas might be serious consequences even a 10 percent diversion from the river. Water wars are predicted between China and India. Irrigation system, canals, barrages, and dams of upstream can be used being political weapons and converted the situation into war.

"Even denial of hydrological data in a critically important season can amount to the use of water as a political tool, warns strategic affairs expert Brahma Chellaney "rivers unite us but dams divide us". (Ramachandran, 2015).

Peter Bosshard from international river network says:

"The race for dam building by both India and China on Brahmaputra coast will cause cumulative environmental impact beyond the limits of river's ecosystem and engaged the livelihoods of more than hundred million people depending on the river" (BBC, 2014)

The Indian Plate collides with Eurasian Plate located very close to China's geological fault line, where various Chinese hydrological projects located in an earthquake-prone area. In this situation Arunachal Pradesh and Assam can be go underwater if earthquake takes place and consequently invite disastrous.

Hydropower dams of located to southwest China and northeast India built on the globe's last free flowing rivers doesn't care about the people living in the region, even also threaten the protected forests, fragile ecosystem and wetland. (Baruah, 2014)

\section{Chinese Claim to India}

China claimed that Indian protest against Chinese dam on Brahmaputra is just to gain support of international community and their sympathy. Chinese development doesn't affect water flow to downstream countries. For China Indian protest again dams is just propaganda. (Zhifei, 2013) Downstream countries will also be equally benefitted by Chinese hydroelectricity projects and dams. China claimed that India has built reservoirs and hydropower stations on Brahmaputra River by strengthening its control over disputed area of Arunachal Pradesh. (Wiley, 2016) According to Chinese scholars India deliberately rising rumors of China threat to water security. They asserted, Indian protest against China is groundless as India by self-hold a large volume of water resources. For China hydropower is a significant source to respond the challenge of impediment to economic growth and energy shortage. (Rosenfield, 2010) North China has serious desertification issues as China is the largest state with 20 percent population of the world while water resources covered only 7 percent of the world. North China consisted of 42 percent population of the country and 8 percent of water resources. (Mishra, 2010) According China dam building will not hold the water of downstream countries, it will merely run river water project aimed and generate power. China promised of equal attention for the protection and development of interest of lower riparian states. (The Economics Times, 2012).

\section{Indian claim to China}

India claimed that China has used water as political weapon against India. Northeastern of India will be heavily devastated by diversion of water. For India water management by the way of river project is not water storage but deadly flash floods. Nutrient rich sediment makes enrich downstream states instead of reaching to the delta river will get back in the reservoir. (Arpi, 2003) China doesn't bother the problems 
facing India. Lower riparian states will be left thirsty when fulfill the Chinese thirst. Social instability, violence, Migration, poverty problems increased due to the reduction of water flow of Brahmaputra. China's construction of dams and hydroelectric project will badly affect the agricultural and industrial sector of India.

By getting Control over water means in Tibet, China will get economic influence over rising power of South Asia. India claim that China will discharge water during rainy period and interception throughout the dry season, and India will be survive on mercy of China. Building of hydro projects and dams on Brahmaputra will lead to water crisis and regional instability in South Asia. By building mega dams China disturbed the statuesque of International flow of water. India claimed that China has adopted the unilateral approach and avoid to communicate to lower riparian states that how construction of dam affect their interests. (Chellaney, 2011) China consume industrial water about 120 billion cubic during a year. China assumption towards water is to ensure social, political, and economic stability. For India China has always been refused to share its hydro engineering plans. In present days water conflict is emerged being security issue and apple of discord between India and China. (Moore, 2018).

\section{Confidence Building}

The Sino-Indian war 1962 halted the progress of Memorandum of Understanding (MoU) an agreement signed in 1954 to share hydrological data. Since 1950-2015 China and India signed about 82 cooperation agreements, 13 of them are about transboundary water cooperation. Four MoUs signed between the two states during 2002-2018 that china will provide hydrological information of Brahmaputra /Yaluzangbu River among the flood season while a MoU signed signed to strengthen cooperation on Transborder Rivers, Ganga Rejuvenation and River development. The MoUs signed by the ministry of water resources of the both states.MoUs signed to provide hydrological information constitutes on 11/13 articles and put enforce for the period of five years (Rosenfield, 2010).

China and India signed implementation plans in 2002, 2010, 2013, 2014 and 2018 for the provision of hydrological information of the Brahmaputra/Yaluzngbu Rivers during the flood season by hydrology and water resources bureau, Central water commission and China, Tibet autonomous region under MWRRDGR (Ministry of Water Resources River Development \& Ganga Rejuvenation). One of them implementation plan of 2014 was replaced with 2013 plan after consensus of China to provide data prior two weeks that would start on $15^{\text {th }}$ May instead of $1^{\text {st }}$ June. The implementation of plans would be remained valid between the periods of corresponding MoUsigned they refined the article of the MoUs so that the duties of each side could be defined more clearly. The current scenario of water cooperation on Brahmaputra River between India and China under MoUs and enforcement of corresponding plans has summarized as follow:

1. India and China cooperation on Brahmaputra River water is being developed but its progress and scope get narrow.

2. For the maintenance and development of cooperation China performed more responsibilities than India that is asymmetrical, so China cooperation with India and sharing benefits on Brahmaputra seemed difficult.

3. According to MoUs and implementation of plans a couple of administrative systems have been established in India and China, for decision making.

i. The Indian system of the Central Water Commission and Ministry of Water Resources (New Delhi) is a parallel system. Sometimes this system doesn't optimal for adequate and reasonable utilization and dissemination of information.

ii. The Chinese system that is organized by Tibet Autonomous region (Lhasa), Bureau of Hydrology and Water Resources, and Ministry of Water Resources (Beijing) is a top down system. 
To cover the cost of operation of hydrological stations and hydrological data India has to pay China under mutual agreement that was started from 2010. Chinese provision of hydrological information before 2010 had been free to India. (Moore, 2018).

\section{Present Situation}

A military stand-off set between India and China in May and June 2020 at difference locations in Ladakh. Even the skirmish took place toGalwanValley theIndian patrolling point 14. After Kargil War 1999 first time foreign armies entered in India skirmish begun in the $3^{\text {rd }}$ week of April and extended to fourth week. Many developments occurred in the first two weeks of May. PLA (Peoples Liberation Army) occupied four territories near Galwan River, one of them is near to Pangong Lake (Smith, June 26, 2020).

Galwan River is flowed from Aksai Chin that is disputed region administered by China and claimed by India. Galwan River originated in eastern area of Samzungling on Karakoram range's eastern sideand flowes to the west and join Shyok River. The river is named after Ghulam Rasool Khan, a Kashmiri who explored river in 1899. The length of the river is about $100 \mathrm{~km}$ and it is fast flowing. China and India shared about $3440 \mathrm{~km}$ long border. The GalwanRiver is located on the western border of LAC at high altitude terrain. According to media reports that troops of both sides clashed on the edge of 14000 feet high along with some soldiers fell into fast following Galwan River 50 miles long in subzero temperature (BBC News, June 25, 2020).

A number of reasons exists of buddying tension, but the roots of the conflict is competing strategic goals and the two sides accused each other., the Chinese Zhao claimed thatGalwanValley is located on Chinese side of LAC, Since April, India build other facilities, new bridges, and new road on most vulnerable area of LAC at Galwan Valley and on Chinese side of LAC. According China, India's infrastructure has seemed to infuriate Beijing. The road has been constructed to boost up the capability of Delhi, so that in case of any war material and men could rapidly transfer. Tension between the two states released in May when India destroyed infrastructure from Chinese side of LAC and withdrew personnel by following agreement signed between the two state's officers. But Indian troops once again crossed Line of Actual Control on 15 June 2020. While agreement was already signed on Galwan Valley. Soldiers and officers made peace negotiations were violently attacked by Indian troops. 20 Indian soldiers were killed in this skirmish (BBC News, 2020).

While on the other end foreign minister of India accused China for breaking agreement. India accused that China has sent thousands of its troops to Galwan Valley of Ladakh and occupied 38000 sq. $\mathrm{km}$ territory in Ladakh. The line shifted due to the presence of Lakes, snowcaps and rivers.

20 Indian soldiers has been killed in narrow ridgeline of Himalayan Range, some soldiers were killed with spiked clubs and metal rods.

The skirmish also invited the report of broadcaster NDTV in India in May that China has appeared 100 meters of Indian side, there appeared now vehicles visible, trenches, shelters and defensive structures even tunnels constructed over Galwan River as well as bulldozers appeared to halt flow of waters. (NDTV, June 24, 2020)

On July 6, 2020 Beijing consent that the two states ready of taking measures to escalate of tension on border after skirmish that takes the life of 20 Indian troops. (The New York Times, 2020).

\section{Conclusion}

This paper explored the Sino-India relations since 1950 to 2020, on water conflicts and endeavors for confidence building measures across the sharing river border. Brahmaputra is the most conflicted river between the two states. Water is the historically budding clash among the two populous states of the world. 
Water scarcity can badly influence the growing population and economic development. Especially conflict on Trans Boundary River on Brahmaputra River will get more sensitivity. Throughout the study we explore that both of them blame each other while building both Hydropower project and dams on Brahmaputra. China built Zangmu Dam, Idea also built Zangmu Dam on Bhutan-India border for hydroelectric power production. Skirmish between the two states at Ladakh also turned towards water disputes and China occupied Galwan River and Panguing Lake. It is extremely expected that China will divert Brahmaputra River while China is committed to take in confidence downstream countries. In the way China has not adopted the policy of absolute sovereignty, in fact China is following the principle of peaceful coexistence and fundamental rules of UN water convention agreed in 1997. India has its own apprehensions for water scarcity in arrears of growing population, irrigation and developing industry need. Effective mechanism required to cool down potential of water conflict as fixed water conflict is a serious challenge to Sino-India relations. The Water conflict between China and India engulfed the whole region including Pakistan, Bhutan, Nepal, Bangladesh, and Afghanistan. All upper riparian states wanted to divert flow of rivers water and bilateral relations between mentioned states are on stake. United Nation and international organizations should introduce agreed transboundary river policy because current skirmish between India and China is the evidence of the failure of cooperation agreements.

\section{Recommendations}

China and India suffering from worst water shortage that can be harmful for food security, so both of them should resolve cross boarder water disputes. (Cox, 2010) Bangladesh, India and China need to plan comprehensive river basin to avoid hydroelectric project impact and geological disaster. Lower riparian states should be taken in confidence by China. Mutual dialogue should be continued to reducing and managing disaster expecting by the use of technology. Collaborative scientific studies also need to undertake to find the cause and effects of glacier melting on the flow of river water. (Kumar, 2012) Water resources of Tibet should be redefined as it covers need of $46 \%$ population of the world. Cooperation on trans boarder river water might be broadening basket of potential benefits throughout downstream and upstream countries (Svensson, 2012).

Collaboration between the two states should be founded on transparency including mutual commitment, dispute settlement mechanism, and information setting to avoid any major disaster. A joint commission of Bangladesh, Bhutan, India and China should be establishe (Iyer, 2015).

\section{References}

Addams, L., Boccaletti, G., Kerlin, M., \& Stuchtey, M. (2009). Charting over Water Future 2030

Water dvisory Group. The World Bank, Washington, DC.

Adeel, Z., \& Wirsing, R. G. (2017). Imagining Conflict Over Water Resources in Himalayan Asia.

Switzerland: Springer International Publishing.

Bajpai, B., Huang, J., \& Mahabubani, K. (2016). China-India Relations: Cooperation and Conflict.

Routledge, New Yark.

Bahadur, P. S. (2004). Overview: Conflict over the Ganga? In PSA, Disputes over the Ganga: A Look

at Potantial Water Related Conflicts in South Asia, Kathmandu, Nepal: Panos Institute South Asia

Jin Wu, j. \& Myers, L. S. (2020). Battle in the Himalayas. The New York Times.

Chellanely, B. (2013). Water: Asia's New Battleground. Georgetown University Press, Washington, D. 
C.

Chellanely, B. (2013). Asian Century: Asia's Resource Scramble, The Kathmandu Post.

Cox, E. (2010). State Interests and creation and Functions of the United Nations Human Rights Council. Journal of International Law and International Relations, Volume 6, 87-119.

FAO. (2019). Aquastat: Ganges-Brahmaputra-Meghna river basin, Food and Agriculture Organization of the United Nations.http://www.fao.org/nr/water/aquastat/basins/gbm/gbmCP_eng.pdf.

Hughes, L. (2013). China Plans for Yarlung Tsangpo River Cause India Concern. Future Direction International Strategic Weekly Analysis.

Navrud, S., \& Godwin, K. (2020). Farmers Preferences for Reductions in Flood Risk under Monetary and non-Monetary Payment Modes. Water Resources and Economics, Volume 30, https://doi.org/10.1016/i.wre.2019.100151.

Bates, G. (2017). China's future under Xi Jinping: challenges ahead, Political Science, 69:1, 1-15, DOI: $\underline{10.1080 / 00323187.2017 .1313713}$

Gehrke, P. C. \& Harris, J. H. (2001). Regional Scale Effects of flow Regulation of Low Land Riverine fish, Wiley Online Library, https://doi.org/10.1002/rrr.648 Indus River Basin. (2011). Food and Agricultural Organization. Retrieved from http://www.fao.org/nr/water/aquastat/basins/indus/indus-CP_eng.pdf

Iyer, R. (2005). India-China-Brahmaputra, Suggestions for an Approach. Economic \& Political Weekly.

Jun, M. (2004). China's Water Crisis: Voices of Asia. East Bridge.

Kumar, K. (2012). Proceeding of Indian National Science Academy. Wadia Institute on Himalayan Geology.

Kumar, D. (2015). Flood and Management in Kosi River. FMISC: Patna.

Li, L. (2005). Xizang Zhi Shui Ziu Zhongguo: Xi Xian Zai Zao Zhongguo Zhan Lue Nei Mu Xiang Lu (Tibet's Waters Will Save China). in Mandarin, Beijing: Zhongguochang'anchu ban she.

Lohani, M. (2013). Harnessing Nepal's Water Resources in National Interest: A book Review, Journal of the Nepal Council of the World Affairs, Kathmandu. 
Map of India's Neighbouring Countries. (2019). MapsofIndia. Retrieved from https://www.mapsofindia.com/neighbouring-countries-maps/india-china-map.html.

Mohan, R. (2018). Ghaghara River System: Its Current Status and Value to Society. The Book: The India River, pp 151-164.

Ojeh, E. (2006). Hydrology of the Indus Basin (Pakistan). Available at: https://webspace. utexas.edu/eno75/HYDROLOGY\%20OF\%20THE\%20INDUS\%20BASIN\%20by\%20 Elizabeth\%20Ojeh.doc. Accessed on: 10/02/2011).

Ramchand, S. (2015). Tripartite Treaty Needed on Sharing Brahmaputra's Water in Asia. Asia Times. Report Casts on Chinese Structures, Soldiers Spotted In Galwan Valley In New Satellite Images. (2020). NDTV

Report cast on Galwan Valley: China Accuses India of Deliberate Provocation. (2020). BBC NEWS. Report Casts on Galwan Valley: Satellite Images Show China Structures on India Border. (2020). BBC NEWS.

Report Casts shadow on bio fuel crops. (2017). Hindustan Times, http://www.hindustantimes.com/india-news/have-not-received-data-on-rivers-from-China-says-ex ternal-affairs-ministry/storyjyFqj071HSoGQogPF1uiUP.html.

Rashid, B.-H. (2013). Proposed diversion of Brahmaputra River by China. Former Bangladesh Ambassador to UN, Geneva.

Rahaman, M.-M., \& Varis, O. (2009). Integrated Water Management of the Brahmaputra Basin: Perspectives and Hope for Regional Development. Natural Resources Forum: A United Nation Sustainable Development Journal 2009.

Singh, D. -S. (2017). The Indian Rivers: Scientific and Socio Economic Aspects. Gateway East, Singapore: Springer Nature Singapore.

Samaranayake, N., Limaye, S.-P., \& Wuthnow, J. (2018). Raging Water: China, India, Bangladesh, and Brahmaputra River Politics. USA: Marine Corps University Press.

Smith, J. M. (2020). The Galwan Killings are the Nail in the Coffine for China and India's Relationsip. FP News.

The Conversation. ( 2016). Academic Rigour, Journalistic Flair. Retrieved from 
https://theconversation.com/china-and-indias-race-to-dam-the-brahmaputra-river-puts-thehimalay

as-at-risk-65496

Uprety, K., \& Salman, S. (2002). Conflict and Cooperation in South Asia's International Rivers-A Legal Perspective. Hegue, Netherland: Kluver Law International.

Vaidya, R.-A., \& Sharma, E. (2014). Research Insights on Climate and Water in the Hindu Kush Himalayas. Kathmandu, Nepal: International Centre for Integrated Mountain Development.

Walker, B., Isabel, H., Huang, Y., \& Yunnan, C. (2014). China's Water Security Crisis. February, Europe, China Research and Advice Network (ECRAN).

Wirsing, R. G., Jasparro, C., \& Stoll, J. D. (2013). International Conflict Over Water Resources in Himalayan Asia. Basinstoke, England: Palgrave Macmillan.

Water, W. (2016). Sino-India Water Disputes: The Coming Water Wars.WileyPeriodicles, Volume 3.

Xie, L. (2018). China's International Transboundary Rivers: Politics, Security and Diplomacy of Shared Water Resources. Florida, USA: Taylor \& Francis Group. 